\title{
研究論文
}

\section{舗装材の表面特性と表面温度の 関連性に関する笑験的研究}

吉田長裕* ·西村 昂**

\section{要 旨}

道路舗装面は，夏季において蓄熱により高温になり，その結果，歩道等道路空間の熱環境に悪影響を 与えている。この実態を定量的に把握するために，歩行者の知覚と物性の両面から熱環境の実態と問題 点を考察した。 その結果，とくに夏季の日中を中心に道路の表面温度が著しく高くなることが観測され， 特に日射や路面の熱気が歩行者の感じる暑さや不快の大きな原因となっており，両者の間に密接な因果 関係があることがわかった，そこで，これらの要因となる舗装材の表面特性に着目し，表面の色と面積 の 2 つ指標を取り上げ，表面温度変動との関係を定量的に分析した.

その結果，表面の明るさを表す明度と表面温度の間には負の相関が見られ，明度を上げることで表面 温度の上昇を抑制できることを示した．また路面に凹凸をつけ，表面積を向上させることが，夜間にお ける路面の熱放射を促進させ，表面温度を下げ得ることを定量的に示した．

キーワード: 熱污染, 道路舗装, 表面温度, 歩行者意識, マンセル表色系, 明度, 表面積

\section{1. 緒言}

近年，環境問題の中でも，ヒートアイランド現象 の問題が指摘されることが少なくない。この原因と して，都市部におけるエネルギー消費の増大や土地 の高度利用，さらには舗装等による人工被覆面の増 加などがあげられており，そのメカニズムの解明に 向けたさまざまな取組みが進められている1〜3).

なかでも，都市部面積の 2 割程度を占めている道 路舗装は，特に夏季において $60^{\circ} \mathrm{C}$ を越す高温に達す ることもあり，熱中症など人体への影響も懸念され 始めている.

そこで，このような都市部での熱環境の実態を明 らかにすることを目的に，著者らは，これまでに代 表的都市内地物の表面温度を実測し，その変動特性 を分析してきた ${ }^{4,5)}$. その結果，夏季における道路 舗装の表面温度が他の地物に比べて著しく高くここ れが歩行空間の気温上昇に少なからず影響を与えて
いることがわかった.

これに対して，近年，施工例が急増している排水 性舗装は，従来の舗装に比べて空隙率が大きいため に表面積が大きく，その結果として熱の発散効率が 上昇すること，また，降雨などの水分を含んだ場合 にはその保水効果が上昇したり潜熱が増加すること によって，表面温度の低下が期待できるものと考え られる ${ }^{6 ; 7)}$ 。このことに関して, 浅枝らは実験, 理 論の両面から，水分の蒸発潜熱を利用することが熱 環境改善に効果的であるとしている8 10).

一方，歩行者環境について考えると，特に夏季に おいて，日射によって高温になった道路表面が，接 地層付近の大気温度の過度な上昇をもたらしている ことから，日射エネルギーを路面で反射させること が効果的と考えられるが，これは歩行者に照り返し による暑さや不快感を与えるとも考えられるため, 歩行者意識からの十分な検討も必要であるといえる.

以上のことから, 本稿では, 道路空間に扔ける路 
面温度に着目し，歩行者意識と表面温度の年変動デ 一夕から，道路空間の熱環境の実態を考察したうえ で，路面の舗装材，色，形状（表面積）などによる 温度の違いを分析することによって，路面温度低減 の具体的な手法について検討すること目的とした。

\section{2．路面の熱特性改善手法}

路面の熱特性に関する問題は，一般にコンクリー トやアスファルト等の比熱が，自然物に比べて小さ いために温度が上昇しやすく，また熱が発散されに くいことに起因している，そこで，この温度上昇メ カニズムに着目した，熱環境改善の試みがなされて きた ${ }^{5,6)}$ ．その主な内容は次のようである.

(1) 路面に凹凸をつけることで表面積を増加させ，熱 の吸収発散効率を向上させる。

(2) 舗装の厚さを増加させること等で熱容量を大きく し，急激な温度上昇を抑える。

(3) 舗装材の透水性や保水性を高め, 散水や自然降雨 による水分の蒸発潜熱を利用して舗装体の温度 を下げる。

(4) 表面の色や表面形状を変化させることで，舗装表 面で日射エネルギーの反射率を増大させ，熱量を 吸収しにくいようにする。

近年施工例が増加している排水性舗装は，これら (1)〜(3)に対応するものとして, 環境や交通安全だけ でなく，熱環境の側面からも注目されている．筆者 らも上述のように，供試体を用いた実験を通してそ の効果を検証した ${ }^{6)}$. その結果, 通常の密粒埔装に 比べて，日中に扔いては表面温度が若干高くなり， 夜間においては約 $1{ }^{\circ} \mathrm{C}$ 程度低くなることが確認され た。しかしながら，この日中に表面温度が高くなる という傾向には，表面色や表面積による影響が考え られるが，これは他の研究結果と異なるものである ことから，その詳細な検討が課題として残された。

(4)については，これまで，黒色舗装の場合に高温 になるといった数多くの実態は報告されているもの の，定量的に害証された例は少なく，日射量と日射 反射量の比であるアルベド值を用いた評価が報告さ れている程度である ${ }^{9)}$ 。このアルべド值は，主に表 面色と表面積に密接に関係した日射エネルギーの反 射率を示す指標であり，これらの要素を独立して扱 ったものではない.しかしながら，これらの要素を 独立した指標としてその影響程度を明らかにするこ とができれば，熱環境に配慮しつつ，地区や道路の
特性をも考慮した多様な路面デザインが可能になる ものと期待されよう。

\section{3 ．道路熱環境の実態}

道路空間における熱環境の実態を把握するため, 本研究では, 物理的状況とそれに対する意識面での 評価を関連づけるための実験と調査を行った. まず, 各種舗装の一般的な温度特性を把握するために，主 要なアスファルト舗装材の年間表面温度変動を把握 するとともに，同期間内に簡単な意識調査を行い， これら両者の関連性を分析した，次に，この結果を 踏まえて，一般的な道路空間における歩行者の熱環 境に対する意識調査を行い，歩行者空間の熱環境改 善の方向を探ることにした.

\section{1 調查および実験の概要}

\subsection{1 舗装表面温度測定と歩行者意識調査}

（1）舖装表面温度の測定の概要

本実験では，熱特性の違いを把握するために，通 常舗装，骨材粒径の異なる $(13 \mathrm{~mm}$ と $20 \mathrm{~mm})$ 排水性 舗装 2 種類の計 3 種類の供試体 $(100 \times 100 \times 6$ $(\mathrm{cm})$ ）を用意し，これらについて同一の自然環境下 における長期的な連続測定（測定間隔10分）が可能 となるよう, 大阪市立大学工学部棟屋上（地上 $6 \mathrm{~F}$ ) に常設した．測定項目は，表1に示すとおりであり， それらの測定箇所については以下の条件に従うこと とした。

(1) 表面温度：熱電対を用いて測定した. 熱電対の設 置は，直射日光による影響を考慮して，表面凹 凸面との間に隙間ができないように測定部をフ イットさせ，その上に断熱材として発砲スチロ

表 1 測定データと測定機器の概要

\begin{tabular}{l|l|l}
\hline 測定対象 & \multicolumn{1}{|c|}{ 測定機器 } & 測定開始日時 \\
\hline 表面温度 & 熱電対 & $\mathrm{H} 09 / 12 / 29 \sim$ \\
\hline 表面湿度 & $\begin{array}{l}\text { アスマン乾湿計 (SK-RHG) } \\
\text { 佐藤計量器製作所 }\end{array}$ & $\mathrm{H} 10 / 05 / 31 \sim$ \\
\hline 日射量 & $\begin{array}{l}\text { 全天日射計 (MS-801F) } \\
\text { 英弘精機 }\end{array}$ & $\mathrm{H} 10 / 02 / 07 \sim$ \\
\hline 気温 & $\begin{array}{l}\text { アスマン乾湿計 (SK-RHG) } \\
\text { 佐藤計量器製作所 }\end{array}$ & $\mathrm{H} 09 / 12 / 29 \sim$ \\
\hline 風速 & $\begin{array}{l}\text { 風杯型風速計 (NO.23-SP) } \\
\text { 太田計器製作所 }\end{array}$ & $\mathrm{H} 09 / 12 / 29 \sim$ \\
\hline 雨量 & $\begin{array}{l}\text { RAIN COLLECTER(Weather LinkIII) } \\
\text { AOR (DAVIS) }\end{array}$ & $\mathrm{H} 10 / 04 / 24 \sim$ \\
\hline
\end{tabular}


表 2 ヒアリング調査のサンプルデータ

\begin{tabular}{|c|c|c|}
\hline 地点名 & 鶴見緑地 & 鶴ヶ丘 \\
\hline 所在地 & 大阪市鶴見区 & 大阪市住吉区 \\
\hline 歩道有無 & あり & なし \\
\hline 道路ランク & 幹線道路 & 地区内道路 \\
\hline 通りの向き & 東西方向 & 東西方向 \\
\hline 植樹帯 & あり(歩車境界部) & なし \\
\hline 沿道土地利用 & 公園·商業 & 住居 \\
\hline 自動車交通量 & 多い & 少ない \\
\hline 自転車交通量 & 多い & 少ない \\
\hline 歩行者交通量 & 多い & 少ない \\
\hline ヒアリング数：男性 & 25 & 28 \\
\hline ヒアリング数：女性 & 93 & 64 \\
\hline ヒアリング数：全体 & 118 & 92 \\
\hline & & 全体：210件 \\
\hline
\end{tabular}

ールを加工したもの（測定部が隠れる大きさ (縦 $15 \times$ 横 $5 \times$ 厚さ $1 \mathrm{~mm}$ )）を被せ, 耐熱テープ で固定した（アスファルト供試体は 4 点).

(2) 気温：供試体付近の地上 $1.0 \mathrm{~m}$ の位置に設置した アスマン乾湿計の乾球に, 熱電対を張り付けて 測定する.

(3) 風速・日射量・雨量：供試体付近に設置.

(2) 歩行者意識調査の概要

調査は, 1998年 9 月から 10 月にかけての晴天 4 日 間の日中（およそ10時〜 17 時）を選び，排水性舗 装が施工されている大阪市内の幹線道路沿いの歩道 上および地区内道路において，主に歩行者を対象に インタビュー形式で実施した（表２）。主な調査内 容は以下のようである.

○暑さの種類とその感じ方

○暑さによる通行頻度への影響と暑さ軽減のための 道路空間構成要素

○暑さの感じ方と物理指標値の関係
両地区の調査で得たサンプル数は210件である.

また，暑さの感じ方と物理指標値の関係を考察す るために, 調査地点において表面温度と日射量を測 定することとした，表面温度は，調査地点で赤外線 温度計（NEC三栄：TH1011）を用いて測定し， 日射量については，大阪市立大学建物屋上での連続 測定データを，アンケート調査実施時間帯に合わせ て抽出した。

\section{1 .2 歩行空間の熱環境に関する意識調査}

路面の違いによる暑さの感じ方の違いを評価する ために，道路や路面の異なる 4 箇所で住民に対する 意識調査を実施した（表 3 ). 回答対象者は中学生 以上とし，世帯毎に対象者分の複数票を留め置き, 後日訪問，もしくは郵便で回収した。調査は1999 年12月に行ったため，同年夏の状況を想定して，主 に自宅前道路の歩行中に扔ける暑さの感じ方と，一 般的な暑さに対する主観的な評価についても質問し た. 回収率 (部数) は81\%で, 有効回答数は395票 であった。

\section{2 道路表面温度と歩行者による知覚}

98 年 3 月 99 年 2 月の 1 力年に抢ける日射量の月 別時間別測定結果を図ー1に示す。これを見ると， 日射量の多い季節・時間帯での道路表面温度は $50^{\circ} \mathrm{C}$ を超えており，とくに $8 ， 9$ 月には日中 $60^{\circ} \mathrm{C}$ 超え ていることがわかる，さらに，夜間においても夏季 には $30^{\circ} \mathrm{C}$ を超えていることから，これが熱帯夜の一 因とも考えられる。

また，日別の最大温度の年間累積曲線をみると (図一2)，1年の半分は $35^{\circ} \mathrm{C}$ 超えており，しかも その半数は $50^{\circ} \mathrm{C}$ を超えていることから, 舗装表面温 度の熱環境への影響が日射量の多い夏場だけに限ら れたものでないことがわかる.

次に，暑さの感じ方とこれらの温度関連指標との 関連性を考察するため，ヒアリング調査の中から，

表 3 調查箇所とアンケート回収の内訳

\begin{tabular}{l|c|c|c|r|r|r}
\hline 調査箇所 & $\begin{array}{c}\text { 歩道設 } \\
\text { 置状 }\end{array}$ & $\begin{array}{c}\text { 道路 } \\
\text { 種別 }\end{array}$ & 路面種類 & $\begin{array}{c}\text { 配付 } \\
\text { 世带数 }\end{array}$ & $\begin{array}{c}\text { 回収 } \\
\text { 世帯数 }\end{array}$ & 有効票 \\
\hline 幹線白歩道あり & あり & 幹線 & 擬石平板 (白) & 100 & 75 & 93 \\
\hline 幹線黑歩道あり & あり & 幹線 & アスファルト歩道 & 100 & 83 & 109 \\
\hline 非幹線歩道あり & あり & 非幹線 & アスファルト歩道 & 100 & 82 & 94 \\
\hline 非幹線歩道なし & なし & 非幹線 & アスファルト & 100 & 85 & 99 \\
\hline 全体 & - & - & - & 400 & 325 & 395 \\
\hline
\end{tabular}


図- 1

道路表面温度の月別時間別 最大值の推移

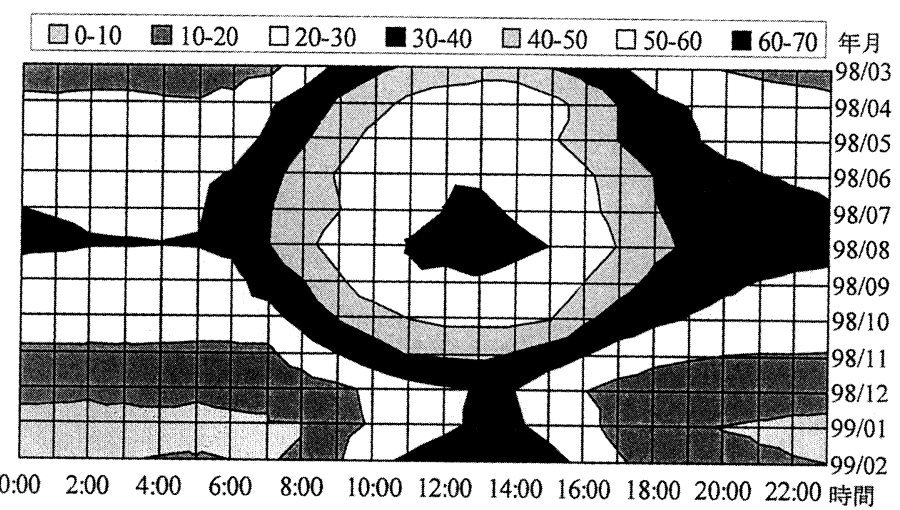

日射量別に「直射日光による暑さの感じ方の 程度」をみると，この両者には明らかな関連 性が認められ，とくに日射量が300 $\left(\mathrm{W} / \mathrm{m}^{2}\right)$ を超えると約 8 割以上の人が日射による暑さ を感じていることがわかる(図ー3）.

一方，表面温度別に「照り返しによる暑さ の感じ方の程度」をみると (図一 4), ここ でも，表面温度の上昇とともにその割合が顕 著に増加しており, 特に, $36^{\circ} \mathrm{C}$ 超えると暑 さを強く感じる人の割合が急激に増加し始 め, $42^{\circ} \mathrm{C}$ 以上になるとその割合は $60 \%$ に達し ている.

以上のことから, 歩行者は温度をはじめと する熱環境指標值に応じて暑さを感じている ことがわかる．このことは，人の知覚面から の暑さに対する詳細な分析によって，その改善策の 検討が可能であることを示唆しているといえよう.

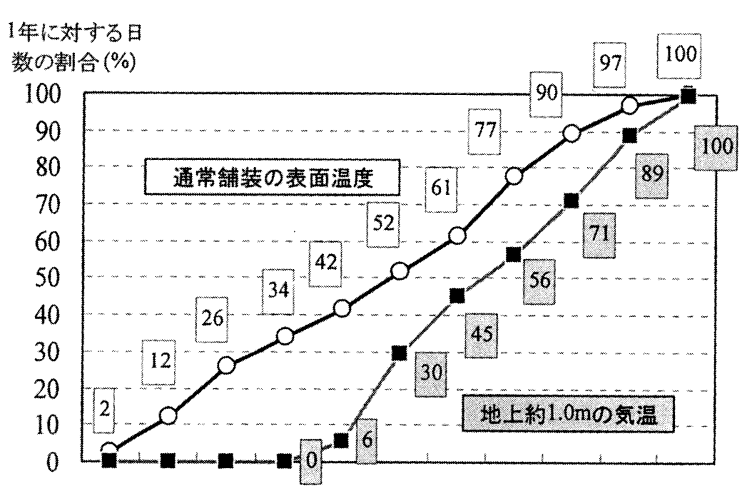

60- 55- 50- 45- 40- 35- 30- 25- 20- 15- - 15 最大温度 $\left({ }^{\circ} \mathrm{C}\right)$

図-2 道路舗装表面の日別最大温度の累積曲線

\section{3 歩行者意識から見た熱環境の実態}

99 年夏，歩行中に暑さを感じた経験のある人は 8
図-3

日射による暑さの感じ方と 日射量の関係

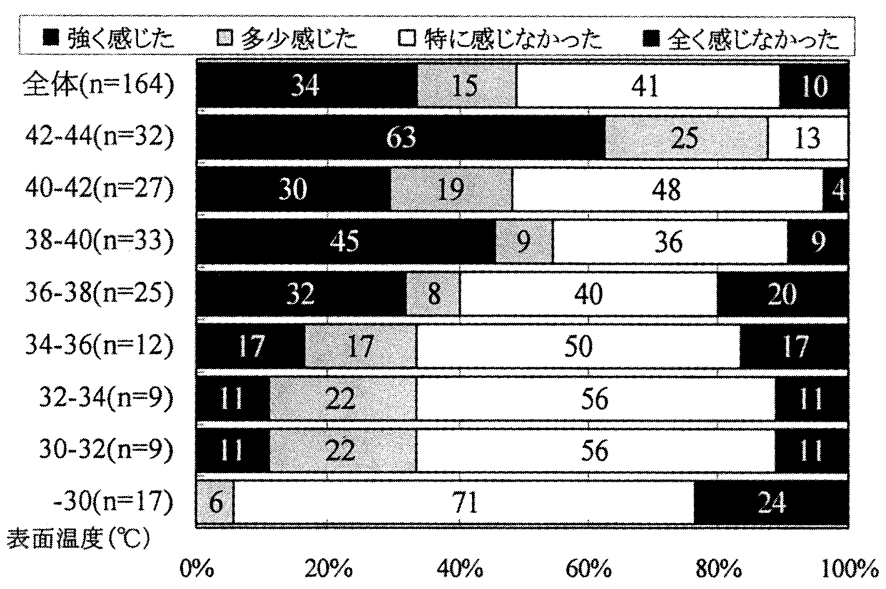


割程度にも達しており，そのうちの半 数近くの人は, 暑さを頻繁に感じてい たことがわかった（図一5）。

そこで，徒歩による外出に対する暑 さの影響を調べた（図一6）。その結 果，55\%の人が必要以上の外出を控え たり，外出時間帯を変更するなどの対 応をしていることがわかった．なかで も，無職の人や主婦層による時間や目 的の自由度の高い外出について，その 傾向が顕著であった。これに対して， 通勤や仕事等の自由度の低いトリップ をもつ職業では,「嫌だが暑さでは予定 を変えない」の回答割合が高く，暑さ に対する抵抗感はあるものの，我慢を 強いられているのが実状と考えられる。

一方，暑さに対する不快感の要因と しては，「路面の熱気」，「直射日光」 に加えて「自動車排熱」や「沿道排熱」 といった人工排熱を指摘する声が大き いことがわかった（図ー7）。このこ とから，日射とそれによる道路表面の 温度が暑さの主原因であり，これに人 工排熱が影響して道路の熱環境をさら に悪化させているといえる.

以上のことから，とくに歩行空間の 熱環境改善のためには, 舗装面の処理 等によって, 路面の温度や熱気を抑え， 反射を促進することが必要であるとい える。

\section{4. 舖装物性の表面温度に対す る影響}

路面の表面温度は, 直射日光をどの ように吸収・発散するかによって決ま り，その要因としては，色や表面積と いった物性が大きく関係すると考えら れる。そこで，98年10月から 99年 2 月の間の測定に，色や表面形状の異な る歩道用擬石平板（供試体サイズ： $30 \times 30 \times 6(\mathrm{~cm}))$ を加えることとし た。供試体は, 予備実験の結果, 明度 差を考慮して, 表面形状 5 種類（通 常 · 洗い出し · 透水小 . 透水大 · 研
、強く感じたロ多少感じた口特に感じなかった 、全く感じなかった 全体 $(n=154)$

$$
700-(n=16)
$$

$600-700(n=16)$

$500-600(n=15)$

$400-500(n=41)$

$300-400(n=24)$

200-300( $n=15)$

$-200(n=18)$

日射量 $\left(\mathrm{W} / \mathrm{m}^{2}\right)$

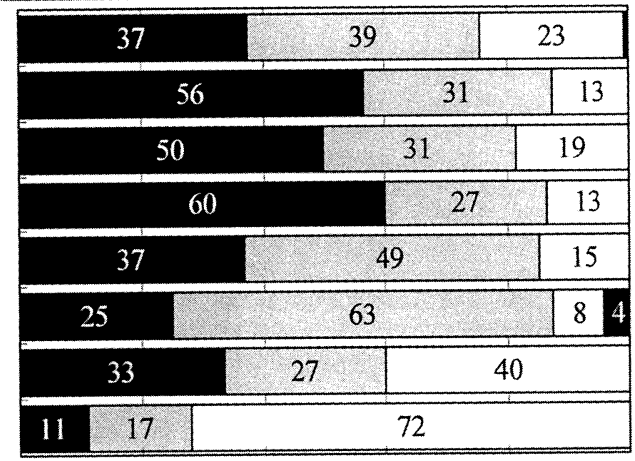

$0 \%$

$20 \%$

$40 \%$

$60 \%$

$80 \%$ $100 \%$

図ー4 照り返しによる暑さの感じ方と表面温度の関係

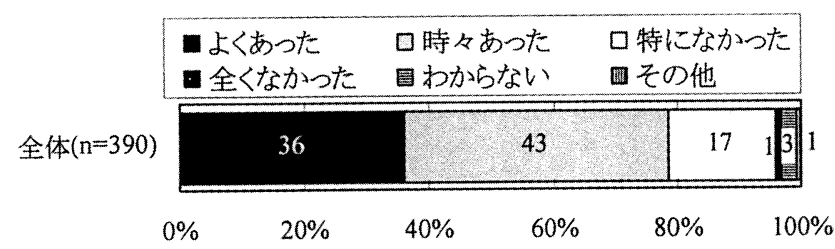

図ー5＼cjkstart夏季における歩行中の暑さの感じた経験割合

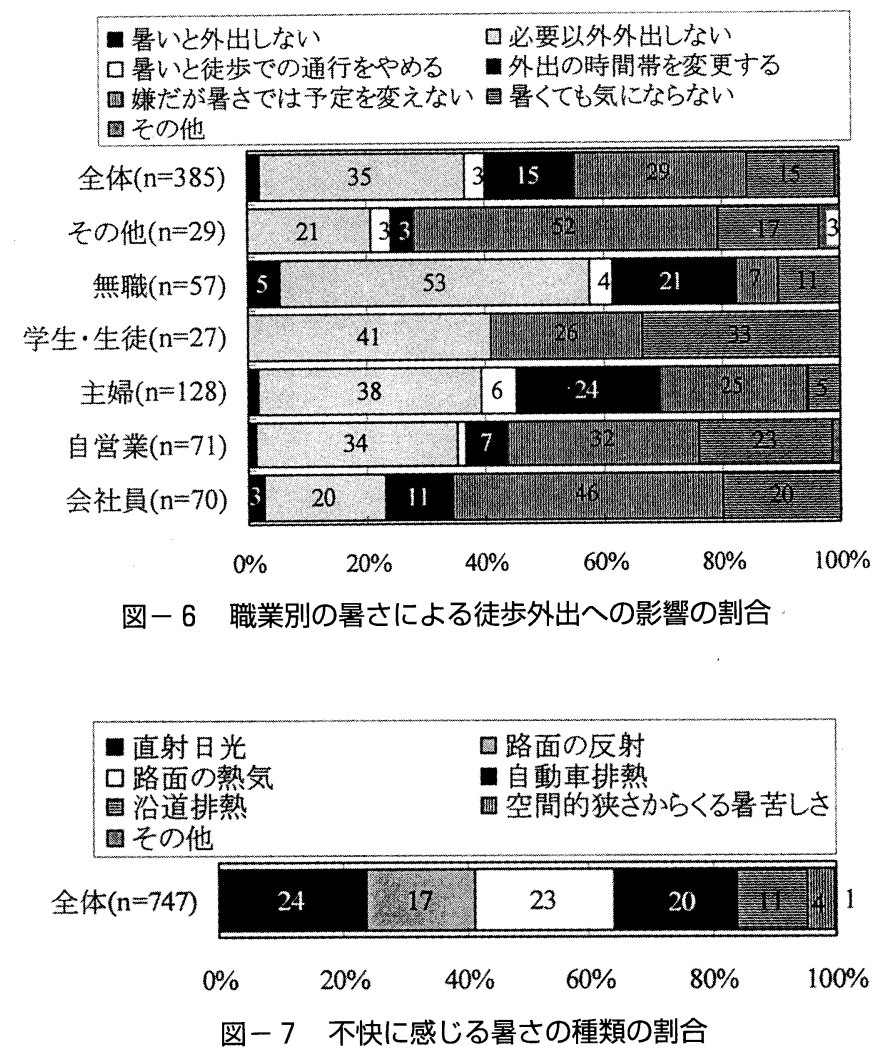


表 4 供試体種類と表面色の測定結果

\begin{tabular}{|c|c|c|c|c|c|c|}
\hline \multirow{2}{*}{$\begin{array}{c}\text { マンセル } \\
\text { 表色系要素 } \\
\text { 供試体種類 }\end{array}$} & \multicolumn{3}{|c|}{ 黒系 } & \multicolumn{3}{|c|}{ 白系 } \\
\hline & 色相 & 明度 & 彩度 & 色相 & 明度 & 彩度 \\
\hline 通常アスファルト埔装 & Y2.1 & 3.0 & 0.5 & - & - & - \\
\hline $\begin{array}{l}13 \mathrm{~mm} \text { アスファルト } \\
\text { 排水性舗装 }\end{array}$ & YR8.3 & 1.7 & 0.3 & - & - & - \\
\hline $\begin{array}{l}20 \mathrm{~mm} \text { アスファルト } \\
\text { 排水性舗装 }\end{array}$ & YR8.5 & 1.7 & 0.3 & - & - & - \\
\hline 通常擬石平板 & PB0.8 & 3.4 & 0.3 & BG7.8 & 7.8 & 0.2 \\
\hline 透水小擬石平板 & PB4.9 & 4.8 & 0.1 & GY4.8 & 5.9 & 0.1 \\
\hline 透水大擬石平板 & Y3.3 & 3.9 & 0.2 & GY2.7 & 6.4 & 0.3 \\
\hline 洗い出し擬石平板 & PB4.0 & 4.5 & 0.7 & $\mathrm{Y} 7.3$ & 6.3 & 0.3 \\
\hline 磨き擬石平板 & PB0.6 & 3.3 & 0.4 & GY2.1 & 7.5 & 0.3 \\
\hline
\end{tabular}

磨）について各々白黒 2 色の計10個とした.

\section{1 物性值の測定方法}

\subsection{1 色の定量化}

色の定量化については，デザイン面でマンセル表 色系が一般的に色見本として普及していることか ら, 本研究では色彩色差計 (オリンパス:CR-200) を用いて色の三要素である色相・明度 · 彩度を測定 した. 表 4 は各供試体毎に 10 回測定の平均值を示し たものである。

\subsection{2 表面積の指標化}

表面積の違いを指標化し, 測定するために, 本研 究では簡便な方法として, 型枠ゲージを用いた。各 供試体の表面上一軸方向 $10 \mathrm{~cm}$ の表面形状プロット 図を CADデータとして取り込んでデジタル処理し， その後, 得られた距離を二乗し, 理想平面積で除す ることで, 理想平面状態に対する供試体面の表面積
表 5 表面積指標（表面積比）の測定結果

\begin{tabular}{l|c|c}
\hline \multicolumn{1}{c|}{ 供試体種類 } & 平均値 $(\mathrm{mm})$ & 表面積指標 \\
\hline 通常アスファルト舗装 & 106.6 & 1.1 \\
\hline $13 \mathrm{~mm}$ アスファルト排水性舖装 & 130.4 & 1.7 \\
\hline $20 \mathrm{~mm}$ アスファルト排水性猞装 & 142.9 & 2.0 \\
\hline 通常擬石平板 & 102.3 & 1.0 \\
\hline 透水小擬石平板 & 104.1 & 1.1 \\
\hline 透水大擬石平板 & 122.4 & 1.5 \\
\hline 洗い出し擬石平板 & 112.2 & 1.3 \\
\hline 磨き擬石平板 & 100.0 & 1.0 \\
\hline
\end{tabular}

比を指標値として用いることとした. 表 5 にその值 を示すが，これらは 5 回の計測に対する平均值であ る.

\section{2 供試体別表面温度の日変動}

図一８は，24時間の日射量と各供試体表面温度の 推移の一例として98年10月11日 (快晴) のデー夕を 示したものである。これを見ると，日射を受けてい る時間帯に顕著な差が現れており, 中でも通常擬石 平板（白）の温度が最も低く，黑系擬石板や通常舗 装で高く，その差は $10^{\circ} \mathrm{C}$ 以上もることがわかる。

\section{3 明度と表面温度}

色と温度の関係を調べるために, 指標值の中で特 に温度と密接に関係する明度について表面温度との 関係をみた。ここで，舗装と擬石平板の材質の違い による温度特性を考慮する必要があるが，温度上昇 時には材質による明確な違いが見られなかったこと から，夜間から昼までの温度上昇時のデー夕のみを 用いて分析することとした。
図-8

表面温度と日射量の24 時間 推移 $(98 / 10 / 11)$

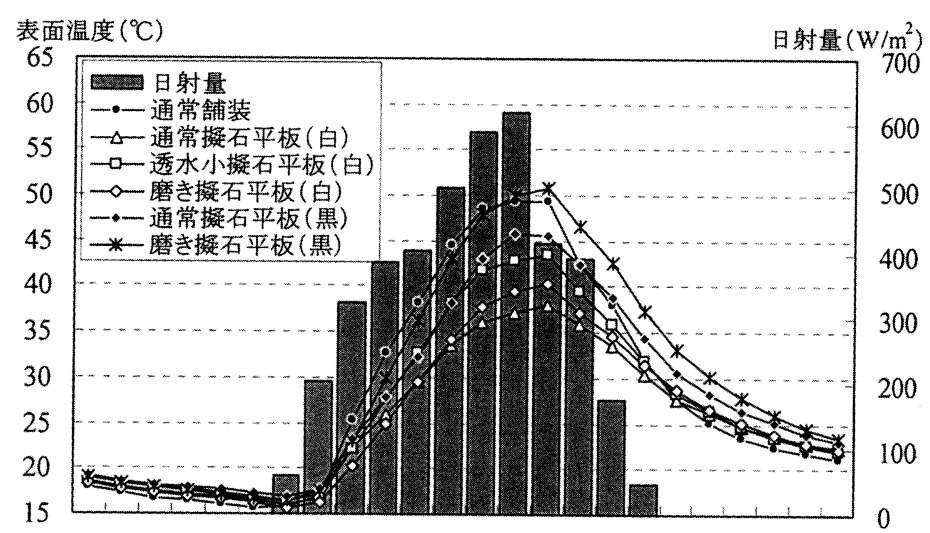

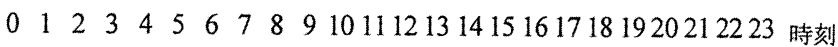


図-9

明度と表面温度の時間変化 $(98 / 10 / 11)$

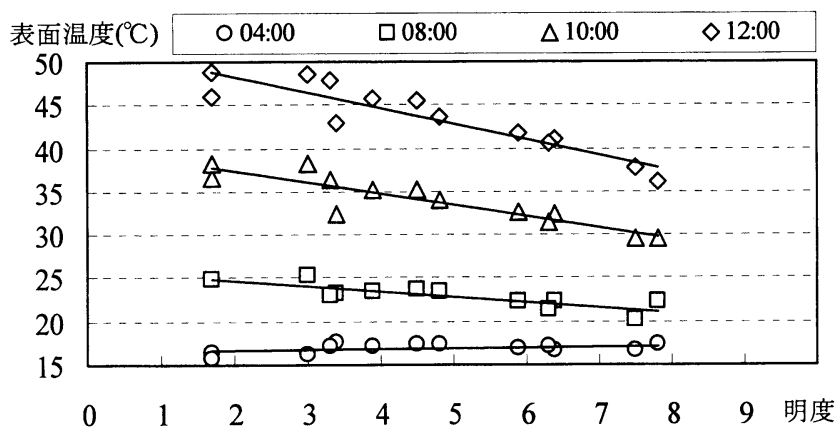

図-10

表面積と表面温度の時間変化 $(98 / 10 / 11)$

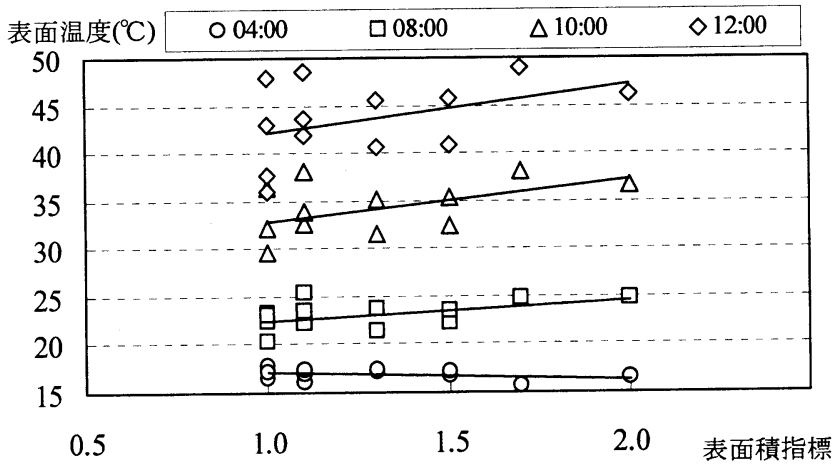

図一9は，明度と表面温度の時間変化を見たもの である。これをみると，4時台では, 明度による表 面温度の差はほとんど見られないが，8時，10時， 12 時台と日射量が多くなるにつれて, 明度の低い供 試体の表面温度が高くなる傾向にある，これは，明 度が日射の反射率と密接に関係するためと考えら れ，舗装表面の温度変動を評価する有効な指標の 1 つとなり得ることを示していると言えよう.

\section{4 表面積と表面温度}

表面積指標值と表面温度の関係は図ー10のようで あり，夜間には，表面積指標が大きくなるにつれて 表面温度が下がるのに対して, 日中では，逆に表面 積指標が大きくなるにつれて表面温度が上昇する傾 向が見られる，これは，日射を受ける表面積が増加 するため日射量も増加するが，日射を受けない時間 帯は熱の放射が進むことに対応していると考えられ る、つまり, 表面積もまた, 表面温度変動の重要な 要素となっていると考えられる.

\section{5 ．舖装物性と表面温度変動の関連}

ここでは舗装表面特性として, 明度指標および表 面積指標を取り上げることにした，とくに，日射の 影響を考慮するため, 降雨から 24 時間以上経過した デー夕の中から， 7 時〜 13 時まで (温度上昇時間帯) と 19 時〜翌 5 時まで (夜間) の 2 グループのデータ を抽出し，それぞれについて日射量と気温デー夕， 各供試体固有の明度と表面積指標を説明変数とし て, 各供試体表面温度を目的変数とする重回帰分析 をおこなった。

\section{1 温度上昇時間帯の特性}

温度が上昇する時間帯のデータ (19,110件) の分 散分析結果を見ると, 日射量と気温には正の, 明度 とは負の有意な相関が見られるが，表面積について は，有意な結果が得られなかった（表 6 )。これは， 日中においては他の気象条件や明度による違いが卓 越していることによると考えられる。また, 標準化 された偏回帰係数の絶対値を見ると, 明度は日射量 の場合の $1 / 2$ 程度となっており, 明度指標が表面 
表 6 表面温度上昇時の分散分析結果

\begin{tabular}{c|c|c|r|r|r|c}
\hline 変数名 & 範 囲 & $\begin{array}{c}\text { 偏回帰 } \\
\text { 係数 }\end{array}$ & $\begin{array}{c}\text { 標準偏 } \\
\text { 回帰係数 }\end{array}$ & $\mathrm{F}$ 值 & $\mathrm{T}$ 值 & $\mathrm{P}$ 值 \\
\hline 日射量 & $0<\mathrm{r}<969.7$ & 0.01 & 0.28 & 11621.6 & 107.8 & $0.0000^{* *}$ \\
\hline 気 温 & $-0.7<\mathrm{r}<36.9$ & 0.98 & 0.79 & 93527.5 & 305.8 & $0.0001^{* *}$ \\
\hline 明 度 & $1.7<\mathrm{r}<7.8$ & -0.59 & -0.12 & 1898.1 & 43.6 & $0.0002^{* *}$ \\
\hline 表面積 & $1.0<\mathrm{r}<2.0$ & -0.11 & 0.00 & 1.7 & 1.3 & 0.1948 \\
\hline 定数項 & & 1.54 & & 90.8 & 9.5 & $0.0000^{* *}$ \\
\hline
\end{tabular}

表 7 夜間の分散分析結果

\begin{tabular}{c|c|r|r|r|r|c}
\hline 変数名 & 範 囲 & $\begin{array}{c}\text { 偏回帰 } \\
\text { 係数 }\end{array}$ & $\begin{array}{c}\text { 標準偏 } \\
\text { 回㷌係数 }\end{array}$ & $\mathrm{F}$ 值 & $\mathrm{T}$ 值 & $\mathrm{P}$ 值 \\
\hline 気 温 & $-2.7<\mathrm{r}<23.9$ & 1.01 & 0.98 & 1032152.2 & 1015.9 & $0.0000^{* *}$ \\
\hline 明 度 & $1.7<\mathrm{r}<7.8$ & 0.06 & 0.02 & 252.6 & 15.9 & $0.0000^{* *}$ \\
\hline 表面積 & $1.0<\mathrm{r}<2.0$ & -1.32 & -0.06 & 2724.7 & 52.2 & $0.0000^{* *}$ \\
\hline 定数項 & & 1.16 & & 629.5 & 25.1 & $0.0000^{* *}$ \\
\hline
\end{tabular}

温度低減に十分貢献する可能性が定量的に示された といえよう。

\section{2 夜間の特性}

夜間における分析（30,420件）では，表面積が負 の相関を示しており, 表面積の増加に伴って夜間の 表面温度が低下する傾向にあることがわかる（表 7)。これは実験結果とも合致する。また明度は, 温度上昇時間帯の結果とは逆の傾向となったが，そ の範囲と偏回帰係数の值が小さいことから，夜間の 表面温度への影響は小さいものと考えられる.

\section{6. 結 語}

本稿では，道路空間における熱環境の実態を物理 指標と歩行者意識から考察し, 人の知覚を考慮した 対応の必要性を示すとともに，その改善の可能性を 探るために, 路面の構成要素の違いによる表面温度 への影響を分析した.

本研究の主な成果を以下にまとめた.

1）道路舗装面は夏の日中に $60^{\circ} \mathrm{C} に も$ 達し, 夜間に も $30^{\circ} \mathrm{C}$ 越えるなど，熱環境の悪化の一因であ る.

2) 人々は日射量や表面温度を知覚して暑さを感じ ており，人の知覚面からの暑さに対する検討が必 要である.
3 ) 自由度の高い外出は，暑さによって時間帯や手 段が変更されており，とくに直射日光や路面の熱 気に不快を感じている。

4）日中は路面の色の明度を上げる（白っぽい色に する）ことで，日射エネルギーを反射し，表面温 度を抑制することが可能である。

5 ）夜間においては表面積を上昇させることで，吸 収した熱を放射しやすくなるため，温度低下に役 立っている.

以上のことから，現状の歩行者空間の熱環境に対 する人々の知覚特性とその要因を示し, 舗装の色や 表面形状によって表面温度上昇を抑え，熱環境を改 善する方法を提示する事ができた。今後の課題とし て，歩行者の「路面の反射」による暑さや不快感と いった意識を考慮した適切な路面材質の提言，ある いは，路面以外の道路空間構成要素も含めた総合的 な熱環境改善の検討が必要になろう。

謝辞：舗装供試体の作成においては，大林道路株式会社に多 大な協力を頂き，また擬石平板は吉野理化工業株式会社に提 供して頂いた。ここに記して感謝の意を表したい。

\section{引用文献}

1 ) 梅干野昆「都市エネルギーに関する実態把握とモデル化 日本建築学会環境工学委員会都市エネルギー小委員会シ 
ンポジウム, 27〜30, (1995)

2 ) 会田勝,「大気と放射過程」, 東京堂出版, (1990)

3 ) 斉藤武雄, 「地球と都市の温暖化」森北出版, (1992)

4 ) 吉田長裕等, 「赤外線温度計による都市地物の表面温度変 動特性に関する一考察」, 土木学会全国大会講演概要, IV-17, (1994)

5 ) 吉田長裕等,「表面温度の変動特性からみた道路舗装への 散水効果に関する基礎的研究」土木計画学研究・講演集, No.20(1), pp.155-158. (1997)

6 ) 吉田長裕等，「排水性舗装による温度上昇抑制効果に関す る実験的研究」土木計画学研究・論文集, No.16, pp.155-158. (1999)

7 ) Nagahiro Y. Et al., 'An Experimental Survey of Water
Sprinkling Effects on Road Pavement Surface Based on the Characteristics of Surface Temperature', Asian Pacific conference on Transportation and the Environment, vol.2 pp.837-845, (1998)

8 ) 浅枝隆等, 「加熱された舗装面上空の大気加熱過程の解析」, 土木学会論文集, No.467, II-23, pp.39-47, (1993)

9 ) ヴタンカ等，「地中水分の分散を利用した夏季の舗装表面 の温度緩和一保水性舗装の利用一」水工学論文集, 40 , pp.449-454, (1996)

10）福田萬大等，「夏季に給・散水した保水性舖装の熱環境緩 和特性に関する実験的研究」土木学会論文集, No.613, V-42, pp.225-236, (1999)

\title{
Experimental Study on Association of Surface Characteristics of Road Pavement with Surface Temperature
}

\author{
Nagahiro YOSHIDA, Takashi NISHIMURA and Yasuo HINO
}

\begin{abstract}
Road pavements generally are raised to a high temperature owing to heat accumulation in summer, thereby consequently giving adverse effects to thermal environment of road space such as pedestrians' pathway.

In this study, in order to quantitatively determine the actual conditions, the thermal environment was investigated together with the problems from the viewpoints of the pedestrian's perception and the surface characteristics.
\end{abstract}

As a result, a remarkably high surface temperature of the road pavement, centering about daytime in summer was particularly observed. Especially, strong sunlight and heatedness of the road pavement gave great causes for hotness and discomfort of the pedestrians, with a close cause-and-effect relationship therebetween. Therefore, the surface characteristics of the pavement material, one of such causes, were remarked, and two indices, coloring and area of surface, were chosen, and the relationships with the changes in the surface temperature were quantitatively analyzed.

As a result, there is observed a negative correlation between the brightness, expressing the luminescence of the surface, and the surface temperature, so that an increase of the surface temperature could be suppressed by increasing the brightness. In addition, it was quantitatively shown that an increase in the surface area by producing ruggedness on the road pavement promoted heat dissipation of the road pavement in night time, whereby the surface temperature could be lowered.

Key Words : heat pollution, road pavement, surface temperature, pedestrian's perception, Munsell color-order system, surface area, brightness 